\title{
Abortion in the Views of Different Religions and Laws
}

\author{
Abass Shafei Ardestani ${ }^{1}$, Mahdi Khaghani Esfahani ${ }^{2} \&$ Seyed Mohamamd Hussieni ${ }^{1}$ \\ ${ }^{1}$ E-Campus Branch, Azad Islamic University, Tehran, Iran \\ ${ }^{2}$ University of Judicial Sciences and Administrative Services, Iran \\ Correspondence: Abass Shafei Ardestani, E-Campus Branch, Azad Islamic University, Tehran, Iran. E-mail: \\ ardestani4646@yahoo.com
}

Received: January 5, 2016 Accepted: February 5, 2016 Online Published: May 29, 2016

doi:10.5539/jpl.v9n4p99 URL: http://dx.doi.org/10.5539/jpl.v9n4p99

\begin{abstract}
More than ever, abortion is paid attention today by public especially in cases that keeping on the pregnancy has problems for mother or there is a fault or keeping the dignity of mother and her family depending on abortion and realizing from its consequences. Therefore, it is too important to obtain abortion verdict. Basically, abortion in all steps of growth evolution from the conclusion of zygote to birth is a decisive prohibition in Islam. The present paper studies abortion and religious verdicts and its effects based on different motivations in the view of religion and law. Further, different forms of abortion and its punishment in Iranian criminal laws are clarified here. Finally, different forms of abortion and their reasons in the views of religion and law are discussed in the present study.
\end{abstract}

Keywords: abortion, religion, law

\section{Introduction}

Abortion is regarded as an action which was seen as sometimes crime and punishable and sometimes as normal and legal. Due to religious and social beliefs, abortion was forbidden in civilized nations. However, there were some exceptions in such periods and it has been admired in many countries that are saving mother's life required abortion (Laws and Society, 111). Principally, abortion is forbidden in many countries due to religious and social expectations. This crime is usually occurred due to some reasons such as family regulation, hiding illegitimate relations, avoiding pregnancy, woman's pregnancy in the absence of man, rape and woman's unfamiliarity with pregnancy prevention tools or the non-effectiveness of such tools. Today, countries have adopted different decisions on abortion; some nations have accepted it unconditionally due to population explosion and have announced it as legal. In Islamic laws and jurisprudence, abortion is seriously treated and is seen as a crime and the perpetrator will be punished by determined penalties. According to the opinion of most Imamieh jurisprudents, if the fetus is aborted in any stage of evolution, it is entitled for punishment and even in some fatwas, it forbidden to destroy the zygote upon conclusion. It is a fact that since past times to now in all human communities, abortion is conducted for different explicit or implicit reasons by mother, parents, physicians and even incompetent individuals as criminal (intentional), shocking (quasi - intentional) and therapeutically (legal). Both individual and collective consciousness are annoyed by many abortions and they are seen as crimes against humanity and negating the right of life. According to the above-mentioned issues, what considered by present paper is how Iranian lawmaker has treated abortion on one hand and the attitude of religion toward it on the other hand. Therefore, fetus and abortion are defined in medical viewpoint and in the views of Shiite jurisprudents in terms of Islamic Punishment Law. As a starting point, we define fetus, abortion and its types.

\section{Literature Review}

\subsection{Fetus Definition}

Fetus is referred to anything covered and hidden. It is also said to zygote when it is in the womb of mother namely a baby that his/her mother womb has covered it and is not born yet. Its origination is pregnancy and the destination is moment before birth.

Fetus passes different steps in mother's womb to get perfect and to be delivered in usual period which is ten months. These are called normal steps of delivery. Different steps of conclusion and evolution of fetus before incarnation which make blood money necessary are as follows: 
- Zygote: The period of entrance and establishment of zygote which is almost 20 days and its blood money is 20 Dinars.

- Grume (a clot of blood): In this period, fetus is converted into a sound and concentrated blood with 4 weeks of age and its blood money is 40 Dinars.

- Morsel (red meat): In this step, fetus is like a meat with 8 weeks of age and its blood money is 60 Dinars.

- Osseous (node-like bones similar to cartilage): in this step, fetus is 12 week age and its blood money is 80 Dinars.

- Fetus is like perfect meat and bones while the spirit has not been incarnated yet with 16 weeks of age and its blood money is 100 Dinars (Islamic Punishment Law, articles 487 and 488).

Another definition is that fetus is the result of pregnancy since the beginning of conception to the moment of delivery since it is covered by womb (Ebn Manzoor, 1408 Lunar, 386). There are also verses in Holy Quran: "he creates you in your mothers' womb" (ZAMR: 6) or "when you were still unborn in your mothers' wombs" (NAJM: 32). It is called fetus when it is in womb and has not been delivered yet (Ebn Manzoor, 1408 Lunar, 386).

\subsection{Definition of Abortion}

Abortion can be studied in different aspects. Therefore, we should point out its lexical and medical definition before its legal one.

Abortion is termination of conception before that fetus gets the capability of living usually before week 20 (McLenan, 1976). In lexical and French definition, abortion is referred to exit fetus due to an unintentional accident or as the result of physical problems or by criminal tools as called early delivery otherwise the criminal reason has caused abortion which is said the woman has lost her child and if it is due to wrong or deficit abortion, it is called wrong delivery (Elias Aftoon, 1979: 304). Both abortion and fetus have Arabian roots used in Persian language. Abortion means occurrence and falling down (Ahmed Edris, 1993: 184 - 189; Hajj: 5; Momenun, 14; Ghafer, 167; Ghyamat, 38; Hor Ameli, vol. 119, Blood Money Chapter: 242 \& 244). Fetus means hidden since it is hidden in the womb of mother whether the fetus is boy or girl. The signs of spirit in fetus are fetus movements, separate heart beat and age over 17 weeks. Abortion means to lose fetus before full growth in womb (Persian Encyclopedia, 2/1894). Its synonyms in Arabic are Ejhaz, Sghat, Emlah and Eslab while they are Abortion, Pregnancy Termination and Aborsement in English) (Private Penal laws, 252) (studying and criticizing the theory on abortion permission in terms of Imamieh Jurisprudents: 76). Medically, almost similar definitions are provided on abortion. An outcome can be seen in this definition: intentional or artificial exit or automatic prior to normal time is called abortion. Legally, more or less similar definitions are provided: "abortion is early delivery so that the fetus cannot live" (Private Penal Law: 1/67). Or "abortion is intentional early delivery so that the fetus cannot live or cutting pregnancy period" (Private Penal Law: 1/158). Some jurists have criticized such definitions and have not considered exit as an abortion condition and have defined abortion as the death of fetus. Also, the have considered automatic death or killing of fetus in womb as fetus (Private Penal Law: 1/253).

\subsection{Types of Medical Abortion}

Medical abortion is referred to intentional/artificial exit or automatic delivery before normal period and or getting out the womb. Legally, it means exit prior to delivery so that it cannot live or abnormal exit from dead mother and incapable to live. Medically, abortion is categorized to different types: (a) normal or disease (automatic) abortion; (b) striking abortion; (c) medical or therapeutically (legal) abortion; and (d) criminal (intentional) abortion.

Normal or disease (automatic) abortion: Abortion by disease happens for fetus, placenta, womb or mother's general diseases. This kind of abortion is conducted despite of the tendency of woman, husband and any other person due to diseases related to mother and fetus without the intervention of a third party in abortion. In this kind of abortion, mother is not liable.

Striking abortion: Striking abortion happens by clashes, accidents and events in which abortion is fully unintentional and perpetrators has no plan for abortion like driving accidents and similar cases in which perpetrator should pay blood money.

Medical or therapeutically (legal) abortion: It is in the cases that keeping on the pregnancy is dangerous for mother or when stopping pregnancy is necessity to save mother's life and to prevent woman's physical and even mental problems. Here, lawmaker has permitted abortion under certain circumstances and receiving the permits 
(studying abortion crime in Iran laws: 36). Concerning this kind of abortion before Islamic Revolution, article 17 of Medical Enforcement Recipe was used which was approved by Health and Judiciary commissions. Accordingly, when abortion is necessary to save mother's life, the physician is obliged to conduct abortion in a hospital and through consultancy with two other physicians. In this case, the reasons, the location and names of advising physicians should be announced to Medical Council's board of directors within 24 hours. After Islamic Revolution, Medical Council's chairman submitted a letter to Guidance Council on the adaptability of medical enforcement recipe with jurisprudential verdicts. Abortion permitting to save mother's life was discussed by jurisprudents and upon obtaining the opinion of Imam Khomeini and reviewing the recipe, articles 6 and 17 of medical enforcement recipe adopted by Health and Judiciary commissions (1969) were diagnosed in contrary to religious norms and it was announced that "in article 17 on the permission of abortion to save mother's health, the cases should be determined. In cases like before incarnation, the spirit or rational fear, abortion is permitted and after incarnation, it is not allowed to abort in order to save mother's life and other cases should be determined and the relevant verdict should be recognized (set of laws in 1984). Currently, therapeutically abortion is conducted under certain conditions before incarnation the spirit. Modus operandi and the conditions to accept the requests and issuing abortion permit issuance is adopted to recipe by Judiciary Head (2003):

1) The request for abortion should be only conducted in provinces' forensic law directorates and in the case of order by judicial authority or the request of parents by physician's introduction letter, it can be admired before incarnation the spirit.

2) Introduction letter by physician should have the photo of patient (stamped by physician), ID card specification, illness diagnosis, the way of diagnosis, symptoms, Para-clinical tests, copies of parents' ID cards and Para-clinical results (with the photo of patient stamped by physician).

3) Concerning fetus indications, conducting sonography in two times and concerning mother indications, at least on sonography to determine the age of pregnancy and providing this letter to physician is necessary.

4) Providing at least two specialized consultancy to confirm diagnosis attached to physician's introduction letter.

5) In cases out of mentioned indications, providing at least three specialized consultancies are necessary to prevent abnormalities which can lead into the death of mother and fetus.

Criminal abortion: Criminal abortion is referred to those ones in which the pregnancy is terminated intentionally. By definition, intentional pregnancy termination is to bring out the fetus intentionally or medical tools. In other words, criminal abortion is referred to intentional killing of fetus by mother or other individuals. Almost all criminal abortions are occurred in the second or third months and it is when the woman understands delays in her regular periods or morning depression and/or is informed of her pregnancy by needed tests. Religiously and judicially, this kind of abortion is a crime and the perpetrator will be convicted by legal punishments.

\subsection{Abortion in the View of Sharia (Religion)}

Shiite jurisprudents have different opinions on abortion before or after incarnation the spirit. Islamic jurisprudents believe that no permission should be issued after conclusion of zygote otherwise the survival of fetus cause serious problems for mother. Such attitudes are investigated in different situations as follows:

- Abortion due to threats against the life of mother

- Threats against the life of mother or fetus or both

- Illegitimate fetus

- Reluctant rape

- Malformed Fetus

- Distress and constriction

\section{Discourse 1: Abortion due to threats against the life of mother}

\section{Shiite jurisprudents' opinions and evidences}

Abortion is allowed in the case of necessity like when pregnancy continuance is troublesome fro woman or her life is in danger. Contemporary Shiite jurisprudents have explicitly issued fatwas in this regard.

Ayatollah Sistani is asked in the regard: "can a mother who do not like to have a child, abort her fetus before 
spirit incarnation while the fetus has no serious risk for mother?" the answer: "she does not have such right otherwise the survival of fetus is troublesome for mother (Hakim, 1279: 284). Ayatollah Lankarani states: "in the case that mother's life depends on abortion, it is allowed and the blood money should be paid. Using pregnancy prevention pills after intercourse are allowed if the woman is sure that she is not pregnant otherwise there are serious dangers for her." Ayatoolah Makarem Shirazi is asked: "if there are hazards against mothers, what is the verdict of abortion of a one-month fetus through husband's consent by injection? The answer: "it is not allowed otherwise in initial steps if there is a serious hazard against mother." "If the mother has no option than treatment and it requires abortion, it is allowed before spirit incarnation" (Golpayegani, 173). In answering a question on abortion, Ayatollah Araki answered: "if it is before spirit incarnation and the physician assures that in the case of fetus' survival the mother would die, abortion is allowed" (Araki, 1994: 250). Imam Khomeini was asked: "a woman is pregnant for 1.5 months. Doctors say that pregnancy is dangerous for mother's life and would cause her paralysis. Is abortion allowed for her?" the answer: "abortion is allowed if there are dangers against mother's life before spirit incarnation" (Vahidi, 1994: 97). Although they have not recourse, one can consider such reasons: the norm of defeating the seditious to corruption, most important on important and losses discount and distress and constriction, a pregnant woman has the right of abortion. When there is a relation between abortion and mother's life or pregnancy continuance is troublesome for woman, the only way to save mother is abortion, and there would be a conflict between keeping the life of a human who is alive and a zygote that its creation is started and its spirit is incarnated. In this case (before spirit incarnation), Sharia rules and principles are obliged to keep the life an alive human since abortion is loss discount. However, if it is after spirit incarnation and connoisseurs believe decisively that pregnancy is harmful for mother, the expedience is to save mother's life. Additionally, mother is principal and fetus is secondary. In retaliation, there is a concurrence among jurisprudents that if a father kills his child, he will not be retaliated. They say: the principal is not killed for secondary. Although this is only a comparison, it can be considered.

\section{Discourse 2: abortion when the life of mother and fetus is threated}

\section{Shiite jurisprudents' opinions and evidences}

Among Shiite jurisprudents, Iranian Supreme Leader, Ayatollah Khamenei believes that abortion is allowed before or after spirit incarnation in the case that one cannot save the life of child and one should select the death of child alone and between the death of child and the death of mother. His opinions are as follows:

Ayatollah Khamenei was asked: "if the fetus is close to certain death and staying it in the womb is dangerous for the life of mother, its abortion is allowed and if her husband follows someone who say abortion is not allowed which woman and her relatives follow someone who says it is allowed, what should be done?" answer: "since in assumption, there is a selection between child's certain death alone and the death of child and mother, there is no option that saving the life of mother by abortion. The husband has no right to prohibit. However, it is necessary that killing the child is not assigned to anyone" (Khamenei, 2006: 281). According to Lankrani, one of the cases in which abortion is allowed when survival of fetus would into the death of mother and child: "one of the cases in which abortion is allowed when is survival of fetus into the death of mother and child or both."

As mentioned before, one can assign such fatwas to loss discount since the loss of losing the fetus is lower than losing the mother and it is not rational to scarify mother for fetus.

\section{Discourse 3: illegitimate fetus abortion}

\section{Shiite jurisprudents'opinions and evidences}

Shiite jurisprudents have considered no difference on aborting an illegitimate whether by rape with reluctance or adultery with consent and they have not allowed it otherwise illegitimate pregnancy of the girl is fault and damages family dignity. In this case, Ayatollah Sistani has allowed abortion before spirit incarnation. He was asked: "a girl's illegitimate pregnancy is too hard for her and would possibly damage her family dignity. Can she abort the fetus?" Answer: "in the case pregnancy is too troublesome and there is no way to save other than abortion, it is allowed before spirit incarnation (Hakim, 2000: 311)." Otherwise, Ayatollah Sistani asserts absolutely that abortion is not allowed due to illegitimacy: "abortion is no allowed even if the fetus is the result of adultery (Sistani, 1420 Lunar: 250).

Likewise, Iranian Supreme Leader does not allow the abortion of an illegitimate fetus: "abortion is haram even if by adultery and father's request cannot be a permit" (Khamenei, 2006: 280). Concerning the abortion for which there is a suspicious whether the zygote is shaped by a Muslim or through adultery, The Supreme Leader asserts that it is not allowed (ibid: 281).

Fazel Lankarani said: "abortion is haram. Therefore, a pregnant woman is not allowed to eat or to do something 
which causes her abortion. Even if a woman is pregnant due to adultery, she is not allowed to abort (ibid). If a woman aborts a fetus through adultery, he has committed a great sin and she should do the following affairs:

- She should repent immediately.

- She should pay the blood money for aborted fetus.

- If the fetus is four months, she should also pay atonement.

\section{Discourse 4: abortion due to rape by reluctance}

There is no difference between verdicts of Shiite and Sunni jurisprudents in hiding adultery whether by the consent of woman or by reluctance. However, some Sunni jurisprudents have allowed abortion in rape by force or reluctance like Yusuf Gharzavi, Jadalhagh Ali Jadalhagh, former president of Al-Azhar and Dr. Mohammad Saeed Tantabi, head of Al-Azhar Community (Omar Ghayem, 1321 lunar: 177 - 178; Bar, 1411 lunar: 63 - 67).

\section{Discourse 5: abortion due to malformed fetus}

\section{Malformed fetus concept}

A malformed fetus is one with mood abnormalities of inherited diseases. Some abnormalities do not cause his death rather they make the life for him, relatives and society difficult since it may have persistent vegetative state and dies after a while. Some deficits can be treated after birth and his/her disease will be cured. Even in other cases, the fetus can be treated inside the womb by advanced machines.

Recognizing a malformed is a new science which was possible in past only upon delivery. Currently, finding this issue is a new problem created by technology and science progresses. By advancements in science and using sonography and genetic tests one can diagnosed malformed fetus.

\subsection{The Reasons of Malformation}

Pregnant mothers' nutrition: In modern science, malnutrition is broadly rose which would cause deficit and illness of child. From a poisoned and deficit zygote, a poisoned and deficit fetus will be created. Such poison may be due corrupted foods, alcoholic drinks, abusing illicit drugs. At the time of poisoning especially drunken, one should avoid proliferation (Jazayeri, 1966: 215). Islamic narratives have introduced malnutrition as the reason of inadequacies while proper nutrition as a malformed fetus prevention. Prophet Mohammad asserts: "give quince to your pregnant women since it may cause the beauty of your child (Majlesi, 1403 lunar: 176). In another narrative, The Prophet states: "give olibanum to your pregnant women since it improves the wisdom of children" (Sheikh Ghomi, 1414 lunar: 570). Regarding the time of zygote conclusion, what achieves by Islamic narratives and human knowledge is that an important part of these deficits are due to parents' ignorance and lack of awareness on the tasks of wives, the way of intercourse and cares during pregnancy. Intercourse between man and woman is answering to a natural need. Although it is natural and instinctive, customs are mentioned for it in Islam (Hasheminejad, 228) and not obeying it would destroy children (Mohseni, 69).

Inheritance: There are other factors like inherited ones which are transferred from parents to fetus. Medically, fetus indications for abortion include anatomical conditions (not formation of fetus' brain) and great congenital abnormalities (heart hyperplasia and nervous system problems) (Shamshiri Milani, 2005: 24). Inheritance is a principle recognized by Islam. Although genetics is a new science in west, inheritance law is mentioned in Holy Quran and Islamic narrations. The Prophet Mohammad asserts: "looking at what location you put your zygote since the ethics of fathers would be transferred to children" (Ibn Ebi Al-Hadid, 1404 Lunar: 116). Imam Sadiq (PBUH) asserts: "when the Divinity wants to create a human, it would gather faces between his fathers to Adam and select one for it. No one should say that this child is not similar to me or my fathers."

In other words, deficits and inadequacies are compensations paid by parents for their ignorance; however, the reasons of such exclusions do not limit to mentioned factors.

External factors: A mother who is exposed by dangerous rays like those ones used to cure such diseases as cancer as well as consumed medicines during pregnancy and diseases which a pregnant woman suffers, all may be transferred to fetus cases his/her malformation.

\subsection{The Opinions of Shiite Jurisprudents}

Only malformation is not seen as a permit for abortion by Shiite and Sunni jurisprudents; however, in inherited illnesses which cause children suffering from them with problems and distress for mother, if it is decisively diagnosed by specialists, most Hanafi, Shafei, Hanbali and contemporary Sunni jurisprudents as well as some Shiite jurisprudents have allowed abortion before spirit incarnation. Iranian Supreme Leader asserts that fetus malformation is not considered as a religious permit for abortion even before spirit incarnation (Khamenei, 2006: 
279). Ayatollah Sistani believes that fetus malformation or the fact that it would live so long upon birth, cannot alone permit abortion (Hkim, 2000: 283 - 284). Concerning abortion, in the case that parents suffer from serious inherited and infectious illnesses, some questions are asked as below:

Iranian Supreme Leader was asked: some parents may suffer from blood diseases and have deficit genes which can be transferred to their children and it is much likely that their children suffer from very serious illnesses. Such children would permanently live in hard condition since birth to death. For instance, patients who suffer hemophilia may face with serious bleeding which can lead into their death or paralysis with a messy strike. Since such diseases can be diagnosed at the first weeks of pregnancy, can we allow abortion in such conditions? Answer: in the illness is decisively diagnosed and retaining the fetus would cause constriction, it is allowed to abort before spirit incarnation but for contingency, the blood money should be paid (Khamenei, 2006: 280 281).

\section{Discourse 6: abortion before spirit incarnation in the case of necessity and distress and constriction}

\section{Distress and constriction}

Constriction mentioned in verse 78 of Hajj Chapter is a personal one like the verdict of ablution and prescription of ablution with sand and negating jihad by old people and patients (Mustafavi, 2011: 318; Mohaghegh Damad, 1995: 75). In the case that the remains of fetus or lack of its abortion cases serious distress of parents and mother's health danger, the generality of abortion prohibition is still respected while in the case of distress and constriction, the prohibition verdict will be changes to permit. Such secondary verdict is used in special conditions. Shiite jurisprudence is based on social necessity and distress and constriction while public jurisprudence is based on Istihsan (preference). In other words, the execution of a religious verdict will be changed under certain conditions (Moosavi Bojnurdi, 1993: 137; Feiz Kashani, 1999: 86; Husseini, 2005: 98). In cases before spirit incarnation, not for life risk but for fetus' disease, the question is that if the fetus causes constriction for he/she or his/her parents, is abortion allowed? In some diseases like thalassemia and hemophilia, in addition to huge costs for life, the people do not have a long life.

\section{The opinions of Shiite jurisprudents}

In answering a question on abortions due to serious illnesses with catastrophic conditions since birth to end of life, Ayatollah Khamenei assert that in the case of decisive fetus of illness and constriction due to retaining such child, abortion is allowed before spirit incarnation. Like Ayatollah Fazel Lankarani, Ayatollah Sistani has allowed abortion before spirit incarnation by unendurable loss (Sistani, 1420 Lunar: 250). Forensic Law Organizational in the only legal authority in Iran that issues the permission of abortion by fatwas of such jurists as The Supreme Leader in the case of necessity as well as distress and constriction before spirit incarnation. According to a paper on therapeutically abortion "abortion is allowed by decisive diagnosis of three specialized physicians and confirmation of Iranian Forensic Law Organization based on fetus' illness due to retardation or malformation which would cause mother's constriction or a disease which threats the life of mother before spirit incarnation (first four months) with mother's consent and there will be no punishment and responsibility for physician."

Iranian Parliament approved this article in 2005 and it was confirmed Guidance Council in the same year.

\subsection{Abortion in Terms of Law}

Lawmaker has not provided definitions on abortion and its types. However, article 492 of Islamic Punishment Law (1991) and article 718 of Islamic Punishment Law (2013) indicate that the blood money of abortion in intentional and quasi - intentional cases should be paid by perpetrator and in pure error is by matron whether spirit incarnation or not. In terms of penal responsibility one can divide abortion into murder like intentional/quasi-intentional or pure error. Legal office says that abortion has special penalty and there is no definition on intention al or errors in discretionary, blood money and other subjective laws. Considering the current concurrence, it seems that one can use definitions in article 2 of retaliation (article 206 of Islamic Punishment Law and article 217 of the same law and article 2 of ex retaliation) on abortion.

\section{(1) Intentional abortion}

In the first period of general punishment law (1925), lawmaker prohibited some cases of intentional abortion by articles 180,181, 182 and 182. In the second period (1983), lawmaker summarized some cases of intentional abortion in two articles 90 and 91 of Islamic Punishment law in a hurry; in the third period (1996), lawmaker removed some deficiencies by articles 622, 623 and 624 of Islamic Punishment Law (private penal law, crime, 250). Articles 90 and 91 of the law ratified by Parliament have provided other expounds: 
Article 90: anyone who enforces a pregnant woman to use tools which lead into abortion will be imprisoned between 3 and 6 months. Anyone means physician or non-physician.

Article 91: if a pregnant woman approaches a doctor or a midwife for abortion and the doctors intentional abort, he/she should pay blood money and in the case of incarnation, he/she should retaliated and if she is guided to use abortion instruments, he/she will be imprisoned between 3 and 6 months. Regarding article 91 of discretionary law indicates contradictories to Islamic punishment law, abortion blood money is as follows:

1) The punishment of a mother who aborts is to pay blood money based on article 489 of Islamic Punishment Law because of the silence of this article.

2) The punishment of abortion by doctor or midwife (someone who has specialty in this regard):

a. If spirit is not incarnated, the punishment of doctor and midwife is to pay blood money.

b. In the case of incarnation and abortion by doctor/midwife, the punishment is retaliation.

c. If doctor/midwife guides abortion instruments, whether incarnation or not, the punishment is 3 to 6 months of prison and for other people 3 to 6 months of discretionary prion. Article 622 of Islamic punishment Law reads: "anyone who causes abortion by striking or harassing a pregnant woman intentionally will be imprisoned for one to three years in addition to blood money or retaliation."

In the following cases, one can consider abortion as intentional:

- Perpetrator has the intention to abort.

- Action or using instruments typically utilized for abortion.

- Abortion is occurred.

Therefore, intentional abortion has three necessary conditions:

- Will in intentional and unintentional crimes is realized the will of perpetrator is not interfered like child and mad

- Perpetrator conducts it intentionally such as striking the victim

- Perpetrator looks for his/her criminal result.

If each condition is not realized, abortion is not intentional and perpetrator is not retaliated; rather, he/she will be convicted to pay blood money or other punishments.

(a) Quasi - intentional abortion

The perpetrator has the intention to strike or harass pregnant woman but he/she was not looking for criminal result namely abortion. For instance, he/she may assault woman without the will of abortion by the woman aborts. According to Article 623 of Islamic Punishment Law, anyone who causes abortion by giving abortion tools to a pregnant woman will be imprisoned between 3 and 6 months and paying blood money based on laws.

Quasi - intentional blood money is not subjected to retaliation and the perpetrator is obliged to pay blood money

(c) Pure error abortion

It means that perpetrator has neither intention to act (harassing) nor criminal result (abortion) but he/she has accidentally caused abortion such traffic offences which lead into abortion or early delivery.

\subsection{The Constituents of Abortion Crime}

Like other crimes, abortion has three legal, material and spiritual elements that are studied here so that one can consider legal punishment by full recognition of this phenomenon.

(a) Abortion crime legal element

1) Intentional abortion by mother

In the case of intentional abortion by mother as perpetrator, she will be convicted to pay blood money and she will have no share in this blood money in terms of article 489 of Islamic Punishment Law.

\section{2) Intentional abortion by a non-specialist}

a. In the case of intentional abortion by a non-specialist who has personally aborted, he/she will be imprisoned between six months to one year in accordance to the first part of article 623 of Islamic Punishment law. 
b. In the case that a non-special guides mother to a conduct a deed which leads to abortion, he/she will be imprisoned between three and six months and blood money payment.

\section{Legal excuse}

If the above two items are approved by which abortion is conducted to save mother's life, imprisonment will be cancelled and the person should only pay blood money.

\section{3) Intentional abortion by specialist}

If those individual who work as physician, midwife, medicine seller or surgery prepare abortion instruments or conduct abortion, they will be imprisoned between two to five years and blood money payment in accordance with article 626 of the Islamic Punishment Law. In this case, more serious punishments are also observed which is due to job characteristic and specialty. However, the problem is that no initiative is taken on abortion verdict by specialist to save mother's life. In other words, this question raises that if physician commits abortion to save mother's life, is his/her punishment discounted or not?

\section{4) Intentional abortion under special circumstances}

If someone commits intentional abortion by assaulting the mother, he/she will be punished by article 622 of Islamic Punishment Law which considers more serious penalties such as blood money payment, retaliation and one to three years of prison.

\section{(b) Material element}

To realize abortion crime, positive criminal behavior namely crime commission of illegal act is necessary and leave of action cannot constitute a material element otherwise where someone has been legally assigned by he/she has not conducted his/her assignment which has yielded to abortion. On this base, material element of abortion can be expressed as follows:

- The attendance of person(s) who committed or were assistant;

- The existence of lively entity;

- The action of perpetrator(s) is subjected to a legal provision;

- Causality relationship between perpetrator and abortion

The action of abortion perpetrator (physician, midwife, etc.) may be manifested as commitment or causality. Article 624 has forecasted the role of physician and midwife in both modes. If physician commits abortion and crime can be assigned to his/her action, he is abortion perpetrator while if physician aborts his pregnant wife, mother is abortion perpetrator and physician is crime assistant. In such cases, Iranian lawmaker has considered special punishments for perpetrator. Overall, abortion instruments may be physical such as abortion or midwifery tools or chemical ones like ampule injection, medicines and medical syrups.

An important point is that physician's guidance should be effective in abortion. In other words, abortion should be initially completed and fetus loses his/her life and, then, there should be causality relationship between physician's act and abortion; namely, it should be recognized that abortion has been due to using physician's guidance by pregnant woman. Obviously, experts can confirm such causal relationship. In the case that fetus is separated from womb by an illegal act but born alive in an abnormal time (e.g. seventh month), criminal action here is the beginning of abortion while some believe that it does not cover such title since if the womb is born alive, it cannot be called abortion and if he/she dies after birth, it is intentional murder not abortion.

\section{(c) Mental (spiritual) element of abortion}

The third element of abortion is criminal intention or ill will. For the occurrence of any crime, criminal intention is necessary but the nature of this intention is not identical in all crimes. Sometimes, perpetrator of a criminal action wants to commit a crime and looks for achieving the results of his/her action. In such case, we say that he/she has criminal intention or ill will and has committed a crime intentionally. In other cases, perpetrator commits a crime willfully but does not want the result and even does not predict such result. In this case, it is seen as an intentional crime or error. Therefore, in intentional crimes, the principle is to prove the existence of criminal intention or ill will while in quasi - intentional crimes and pure error, it is necessary to prove error. In intentional crimes, mental element constitutes a criminal error rather than ill will.

\subsection{Spiritual Elements in Intentional Abortion}

According to article 622 of Islamic Punishment Law, anyone who causes abortion by striking or harassing a woman, will be imprisone3d between one to three years in addition to blood money payment and retaliation." It 
means that perpetrator should commit abortion by such intention. Therefore, if there is no intention or the perpetrator did not know that the woman has been pregnant, he cannot be punished by such basis and ill will is particularly remarkable. In this article, since the condition of this article is that the striker knows that she is pregnant while he has not abortion intention or in posing damages, he does not know that she is pregnant but it will not be subjected by this article and he can be punished for other physical damages. As it was already mentioned, perpetrator of abortion would conduct his quasi - intentional action willfully but does not want its result. For instance, he would like only damage victim but was not looking for a criminal result namely abortion. For example, he has assaulted a woman without knowing that she was pregnant and the abortion happens and/or perpetrator gives a medicine to woman without the intention of abortion but the medicine causes abortion. Article 623 of Islamic punishment Law says that anyone who cases abortion by giving sub substances or other instruments will be imprisoned between 6 months to one year and blood money adapted to relevant regulations. The contrary concept of article 622 is spiritual element in quasi - intentional abortion and to prove quasi intentional error and causality with result. Quasi - intentional abortion is not subjected by retaliation. What mentioned before is an overall norm on unintentional crimes (quasi - intentional and pure error) relied upon criminal error approval by crime perpetrator. Therefore in abortion crime, pure error is the realization criminal error by the implications in article 715 and 716 of Islamic Punishment Law in terms of improvidence, carelessness, not respecting governmental requirements or lack of driving skills by a motor vehicle. As mentioned explicitly in article 714 of Islamic Punishment law, whenever improvidence, carelessness, not respecting governmental requirements or lack of driving skills (ground, sea and aerial vehicles) (or a motor vehicle leads into unintentional murder, perpetrator is convicted to ...). As a result of spiritual element in pure error abortion, the realization of criminal error is on side of offended driver.

\section{Private elements of abortion crime}

As we know, in addition to general elements of abortion which are necessities for the realization of any crime, it is also necessary to study crime private elements. Here, we study abortion crime private elements:

The existence of fetus: Abortion is a crime obliged to result. It means that the result namely abortion of a pregnant woman should be realized. Exiting something except than the fetus from mother's womb is not considered abortion. According to some jurisprudents, if something aborted cannot be diagnosed by specialists or physicians only for the pain of mother cannot lead into conviction. Article 493 of Islamic Punishment Law and article 721 of the same law (2013) read:

In the case that something is exited from woman that its origin cannot be proved by specialist physician, it would have no blood money and compensation while if mother is damaged to this, the perpetrator will be convicted to blood money payment or compensation.

Early exit of the fetus: For the realization of abortion crime, there is no difference between the first and the last months of conception. Early exit before normal time cannot lead into abortion in all cases; rather, in such cases, other conditions are necessary. Since abortion considers the cases in which a lively fetus is died, early delivery in which the child can continue his/her life has its own definition of abortion.

Ill will : To realize a criminal act, the existence two general intentions and particular intention are necessary. General intention means that perpetrator is aware of pregnancy and his/her intention is to commit abortion. Particular intention means to conduct an act to achieve a result. In the case of the existence of these two elements, perpetrator is subjected to articles 623 or 624 of Islamic Punishment Law (2013). Otherwise, he/she will be convicted to pay blood money.

Utilizing special instruments: Positive action, material pillar of abortion in not leave of action as assistance or giving tools either physical or chemical like abortion and midwifery or chemical ones like ampule injection or syrups and substances; article 623 of Islamic Punishment Law (2013) reads: anyone who causes abortion by giving substances or other tools will be imprisoned between six months and one year.

An important point is that physician's guidance should be effective in abortion. In other words, abortion should be initially completed and fetus loses his/her life and, then, there should be causality relationship between physician's act and abortion; namely, it should be recognized that abortion has been due to using physician's guidance by pregnant woman.

\section{Conclusion}

A malformed fetus is one with mood abnormalities of inherited diseases. Some abnormalities do not cause his death rather they make the life for him, relatives and society difficult since it may have persistent vegetative state and dies after a while. Some deficits can be treated after birth and his/her disease will be cured. Even in other 
cases, the fetus can be treated inside the womb by advanced machines.

When the fetus suffers a non-curable disease, it is called as malformed fetus. The permission of aborting such fetus is different among Shiite and Sunni jurists before and after spirit incarnation. Most jurists have ordered to abortion before spirit incarnation even though is seen as a haram and illegal act and no permission is predicted for it; in some special cases, however, serious deficit is of fetus would cause distress and constriction for the society and family. In such cases, jurists have allowed abortion. However, all Islamic jurists believe that abortion upon spirit incarnation is haram.

\section{References}

A series of laws. (1984). Gazette.

Aghayinia, H. (2005). Private criminal laws, crimes against individuals. Tehran: Mizan Publications.

Ahmed Edris, E. (1993). Blood money (Trans: A.R.Feiz). Ministry of Culture and Islamic Guidance, vol. 1.

Al-Jaziri, A. (1998). Al-Fegh Ala Al-Mazaheb Al-Rabei. Beirut, Dar Al-Saghalayn.

Ameli, Sh. H. (2010). Vasayel Al-Shiyeh (5th ed.) Tehran, Al-Matab Al-Eslamieh.

Araki, M. R. (2009). Ershad Al-Sayel (Arabian questions). Qom.

Ebn Ebi, A. H. (1983). Nahjolbalagheh description, Qom, Ayatollah Marashi Najafi Library.

Ebn Manzoor. (1987). Lesan Al-Arab, author: Ali Shiri, vol. 1, Beirut, Dar Ahya.

Elias, A. (1979). Al-Famus Al-Asary (Arabic - Persian new encyclopedia). (Trans: S.M. Tabataei), Islamieh Publications, vol. 2.

Feiz Kashani, M. M., \& Ebn Shah, M. (1999). Safineh Al-Nejat (Trans: M.R.Dorudian Tefreshi).

Ghazei, S. (2010). Forensic law book, University of Tehran Publications, p. 536.

Golduzian, I. (2001). Private criminal laws (8th ed.). Tehran, University of Tehran Publications.

Golpayegani, M. R. (2009). Ershad AL-Sayel (Arabic Steftaat), Qom.

Gudarzi, F. (2012). An introduction on forensic law. Judicial Police University Publications.

Hakim Abdulhadi, M. T. (1999). Jurisprudence for westerners based on the fatwa of Ayatollah Sistani (Trans: S.E.Seyed Alavi). Qom: Ayatollah Sistani Publications.

Hasheminejad, S. A. (2009). Answering the youths' questions, Religious Discussion and Critics Center Publications.

Husseini, H. (2005). Legal transformations of Australian abortion in a global trend mirror with a short review of Iranian laws and the legal basics of regulated liberty. Radical Rights Journal, 5.

Jazayeri, Gh. (1966). The miracle of foods. Tehran: Parasto Publication.

Khamenei, S. A. (2006). Resaleh Ajvab Al-Esteftat, Tehran: International Publications Company affiliated by Amir Kabir Publications.

Majlesi, M. B. (1982). Bahar AL-Anvar, Beirut, Dar Ahya A-Tarath Al-Arabi.

McLennan, Ch. (1976). A summary of midwifery (Trans: A.Sarvarbakhsh and H.Talebzadeh). Tabriz University Publication.

Moafari, A. (1999). Studying abortion crime in Iranian Laws. Trial Monthly Journal, 15.

Moeen, M. (1999). Persian Encyclopedia (Vol. 1 \& 2). Tehran: Amir Kabir Publication.

Mohseni, M. A. (2010). Al-Fegh Van Al-Masayel Al-Tabiyeh. Qom: Yaran publication.

Moosavi Bojnurdi, S. M. (2008). Jurisprudential rules. Tehran: Majd Publication.

Mustafavi, S. K. (2011). Jurisprudence rules (1st ed.; Trans: A.Fahimi). Tehran: Mizan Publications,

Noory, R. (2008). Abortion in Islamic Punishment Law. Legal and Judicial Journal, 5, 47.

Omar Mohammad, Gh. (1942). Ahkam Al-Janin Fi Al-Fegh Al-Islami, Darolandals.

Shamshiri Milani, H. (2005). Abortion and mother's life right. Fertility and Infertility Quarterly Journal.

Sheikh Ghomi, A. (1995). Safineh Al-Bahar, Qom, Darolasvad.

Sistani, S. A. H. (1999). Selection of problems explanation (2nd ed.). Qom: Ayatollah Sistani's Publications 
Office.

Vahidi, M. (1994). Ladies'verdicts. Qom: Islamic Propaganda Office.

\section{Copyrights}

Copyright for this article is retained by the author(s), with first publication rights granted to the journal.

This is an open-access article distributed under the terms and conditions of the Creative Commons Attribution license (http://creativecommons.org/licenses/by/3.0/). 